\title{
Large scale three-dimensional pit slope stability analysis of the structurally controlled mechanism in Mae Moh coal mine
}

\author{
A Chaiwan Chiang Mai University, Thailand \\ C Leelasukseree Chiang Mai University, Thailand \\ N Mavong Electricity Generating Authority of Thailand, Thailand
}

\begin{abstract}
Mae Moh Mine is the largest open pit coal mine in the Southeast Asia, which coal production, is used wholly for 14 percent of Thailand electricity generation. The great challenge in the very near future is the stability of the massive great wall, called 'C1-Westwall' area. The batter is susceptible to the risk of the large scale blocks sliding determined by the geological structures and discontinuities, such as faults, joints, weak layers and bedding plane shears, abundantly existing in the under burden rock mass. The potential sliding rock mass of more than 200 metres high batter could be susceptible to the catastrophic event and affects to the continuity of the project. The wall conceptual adjustment was initially proposed in 2013, concerning with approximately 43 million cubic metres of under burden rock mass which would be excavated according to the old mine master plan. The review of geological structures has shown that there is the possibility to re-design the shape of this wall portion which could be led to the substantially waste removal cost saving. Due to the nature of the area of interest, complex geological setting make the problem should be considered in the three-dimensional. The evaluation of wall stability for safe and feasible mining, the 3DEC ${ }^{\circledR}$ (Itasca Consulting 2007) was selected as the tool of the trade by the advantage of discontinuum modelling approach, which facilitates the explicit joints modelling. Block joints cutting models with statistical orientations of bedding planes were analysed to get the results and better understanding of the rock blocks movement tendency in relation to the orientations of controlling structures. Another benefit which has been gained from this 'experiment' is the awareness to the potential hazard that proved to be existed and still be needed to be thoroughly evaluated. This is the first step to the efficient slope re-design procedure of the Mae Moh Mine pit wall, for the long-term mine planning.
\end{abstract}

\section{Introduction}

Mae Moh Mine is the largest open pit coal mine in the Southeast Asia, located in the northern region of Thailand. The mine was operated and managed by the Electricity Generating Authority of Thailand (EGAT), the energy government business enterprise. The coal production, approximately 15 to 17 million tonnes per annum, is used wholly for 14 percent of Thailand electricity generation.

The coal deposits in Mae Moh tertiary basin were discovered by the local inhabitants more than one hundred years ago. The coal mining has been rapidly developed since the 'oil crisis' in 1975 . To support the project expansion, the technical supports via the cooperative programme, called the Thailand-Australia Lignite Mines Development Project with the assistance from the Australian Development Assistance Bureau was established. The latest surface mining technology and knowledge, at that time, were deployed to the EGAT engineering staff. The complete geological and geotechnical investigation for the definitive mining study were also carried out. The open pit slope engineering is one of the most valuable 'know-how' legacy from that time.

At the present, the pit covers the area approximately $7 \times 4 \mathrm{~km}^{2}$, with the pit bottom nearly $300 \mathrm{~m}$ from the pit rim elevation, as shown in Figure 1. The total project has been planned to continue the surface mining onward to 2051, which the deepest point will be more than $500 \mathrm{~m}$. 


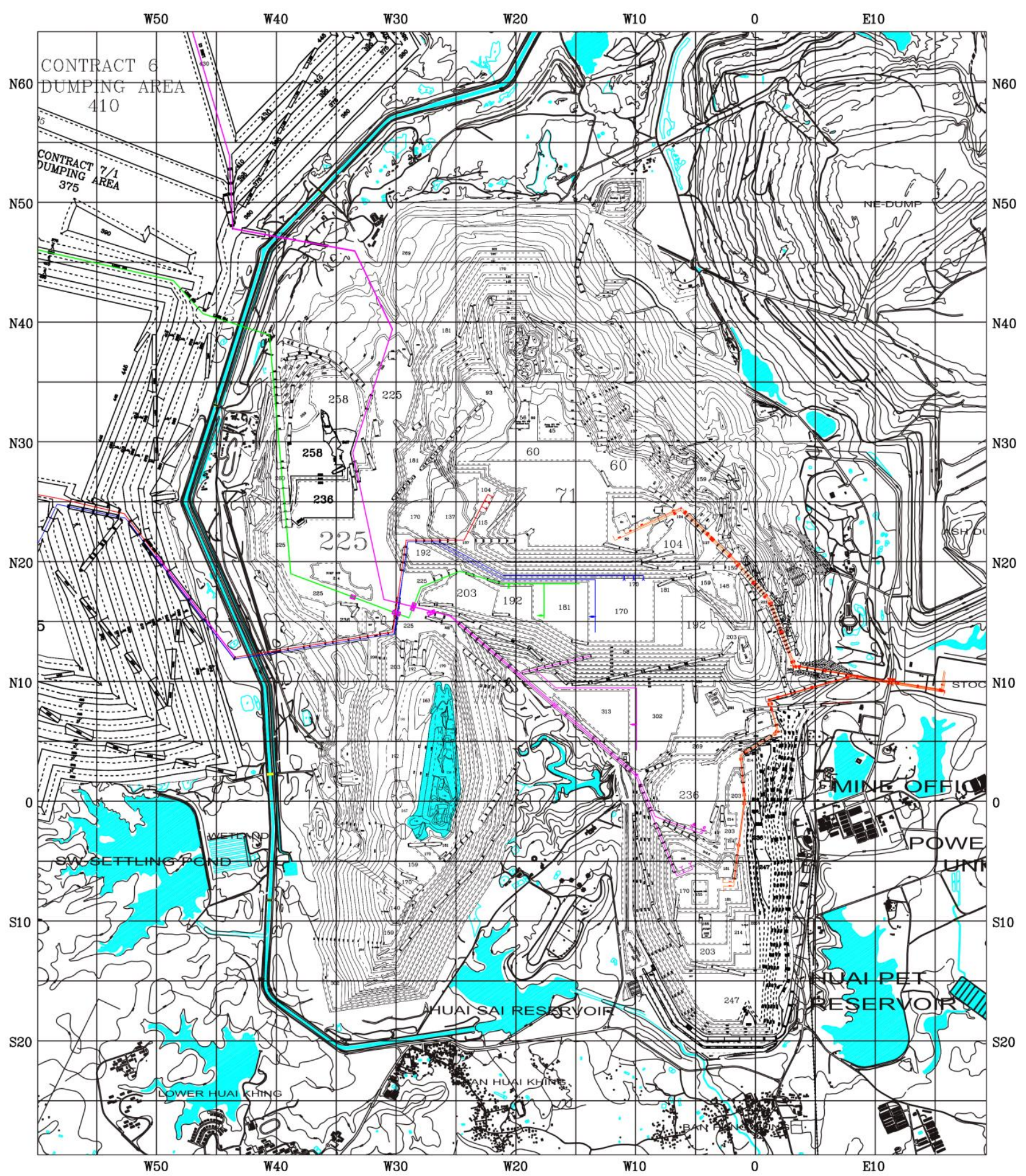

Figure 1 Mae Moh Mine stage plan, the pit situation at the end of 2015 (Mine Engineering Department 2015), aligned to mine grid rotated counter clockwise from the UTM north $24^{\circ} 31^{\prime} 41.37^{\prime \prime}$ with grid spacing $500 \times 500 \mathrm{~m}^{2}$. The pit centre coordinates approximate in line N10, W20 and the active mining area which is in the middle of the map, from N10 up north, called ' $\mathrm{C} 1$ ' area

One of the geotechnical challenges in the very near future is the stability of final pit wall called 'C1-Westwall'. According to mine master plan, the batter will be nearly $200 \mathrm{~m}$ high with the opening length up to $700 \mathrm{~m}$ as shown in Figure 2. This massive great wall is susceptible to the risk of the large scale blocks sliding determined by the geological structures and discontinuities, such as faults, joints, weak layers and bedding plane shears, abundantly existing in the under burden rock mass. 


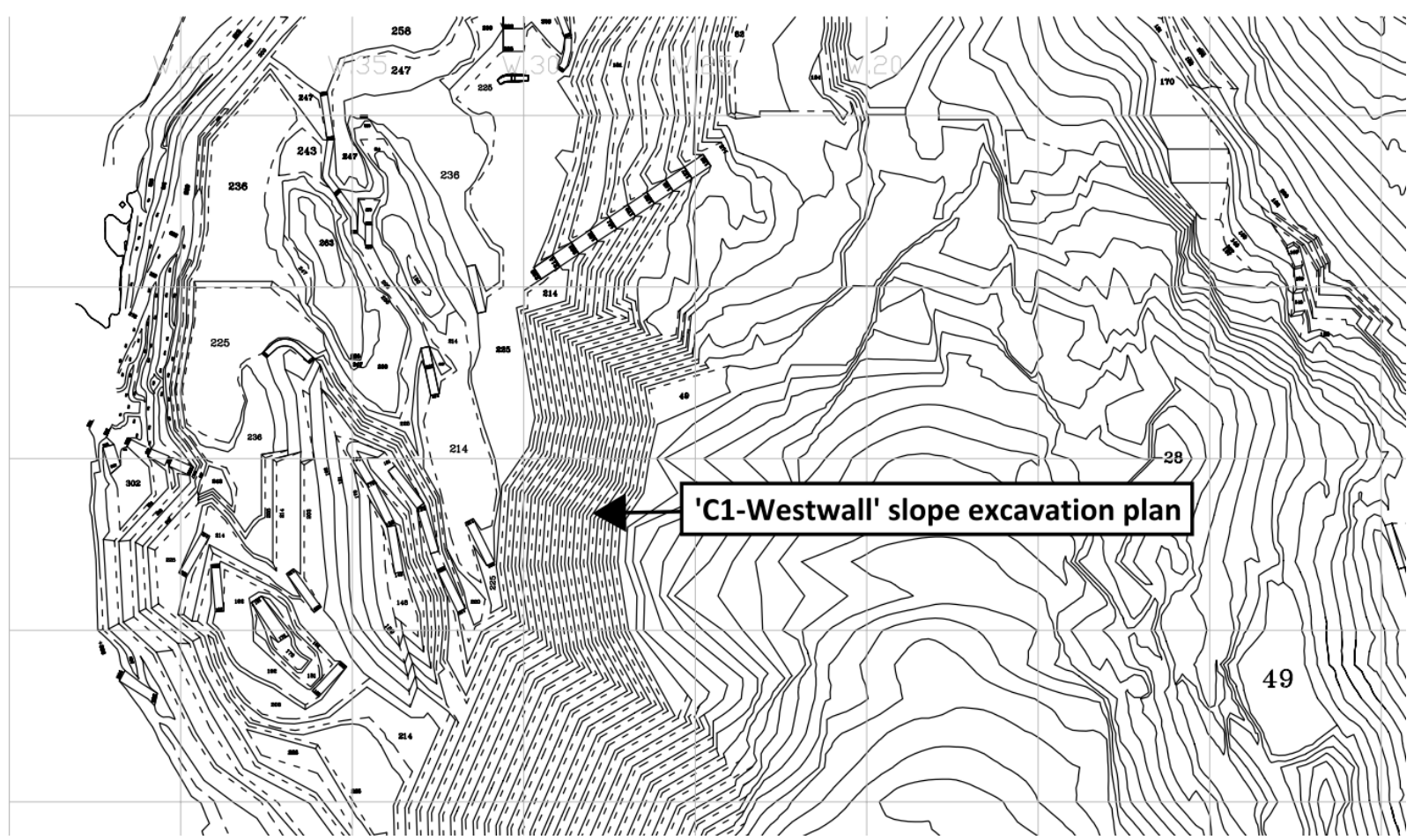

Figure 2 C1-Westwall nearly 200 metres high batter according to mine master plan

In 2013, the wall conceptual re-design was initially proposed. The concept is concerning with approximately 43 million cubic metres of under burden rock mass which there is the possibility to be left in-place instead of being excavated (Figure 3) that could be led to the substantially waste removal cost saving.

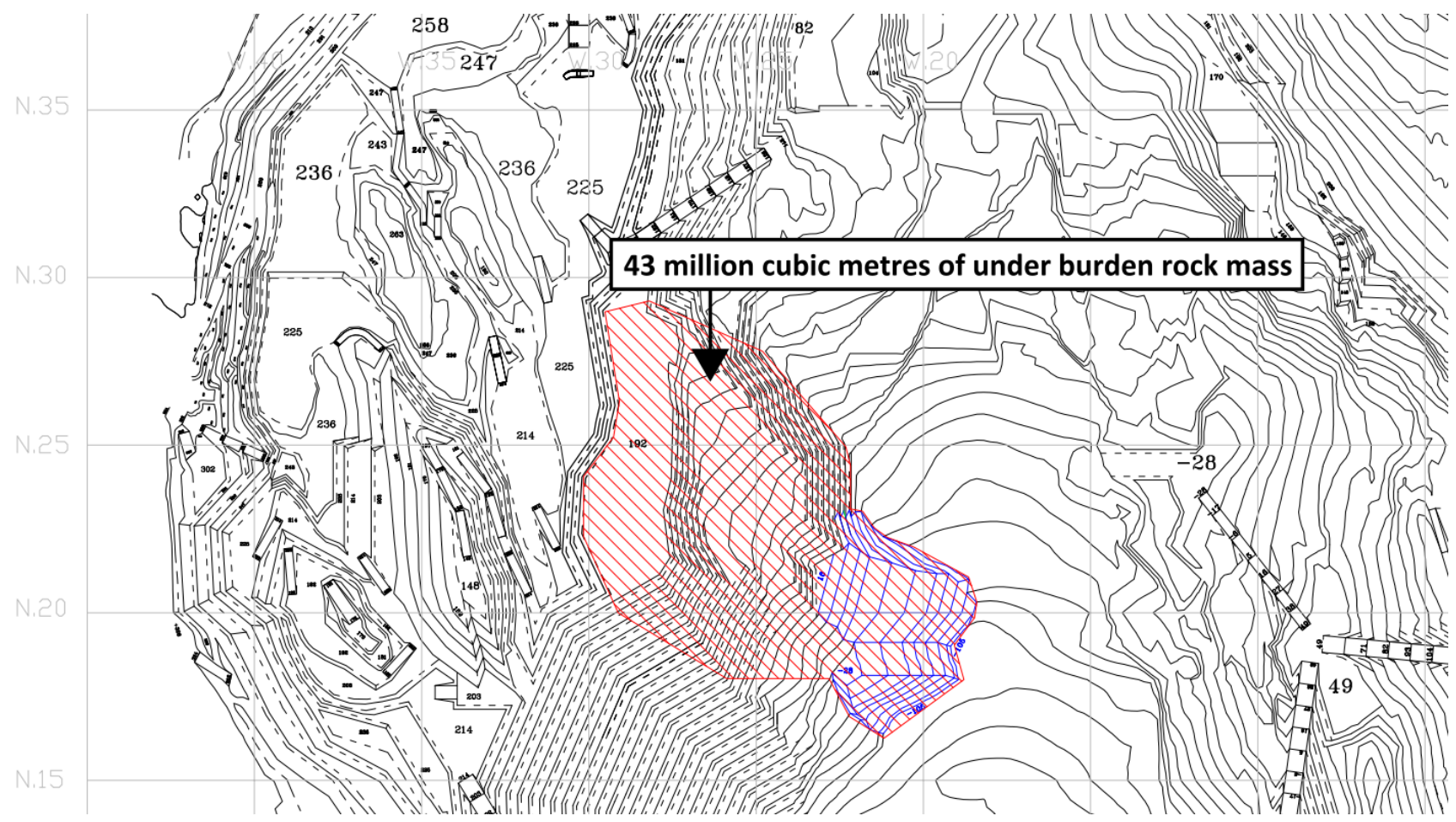

Figure 3 C1-Westwall re-design concept proposed in 2013

This adjustment concept was needed more thorough consideration especially for the long-term pit wall stability. Due to the nature of the area of interest, complex geological setting make the problem should be considered in the three-dimensional (3D). In the preliminary step, the analysis was intended to examine on rock blocks movement tendency which would be expected to depends on the variation of the bedding 
structures orientation and dipping. 3-D numerical modelling, 3DEC ${ }^{\circledR}$ (Itasca Consulting 2007) was selected as the tool of the trade by the advantage of discontinuum modelling approach, which capable in the explicit joints modelling, and suitable for discrete rock blocks mobilise on the bedding shears plane case of Mae Moh Mine.

\section{C1-Westwall geological considerations}

The C1-Westwall is located in the western side of $\mathrm{C} 1$ active mining area with complex geological setting of faults, bedding shears and jointing system, as shown in Figure 4. The rock mass of final pit wall will be composed mainly of under burden grey claystone which underlying the coal beds, as shown in Figure 5 .

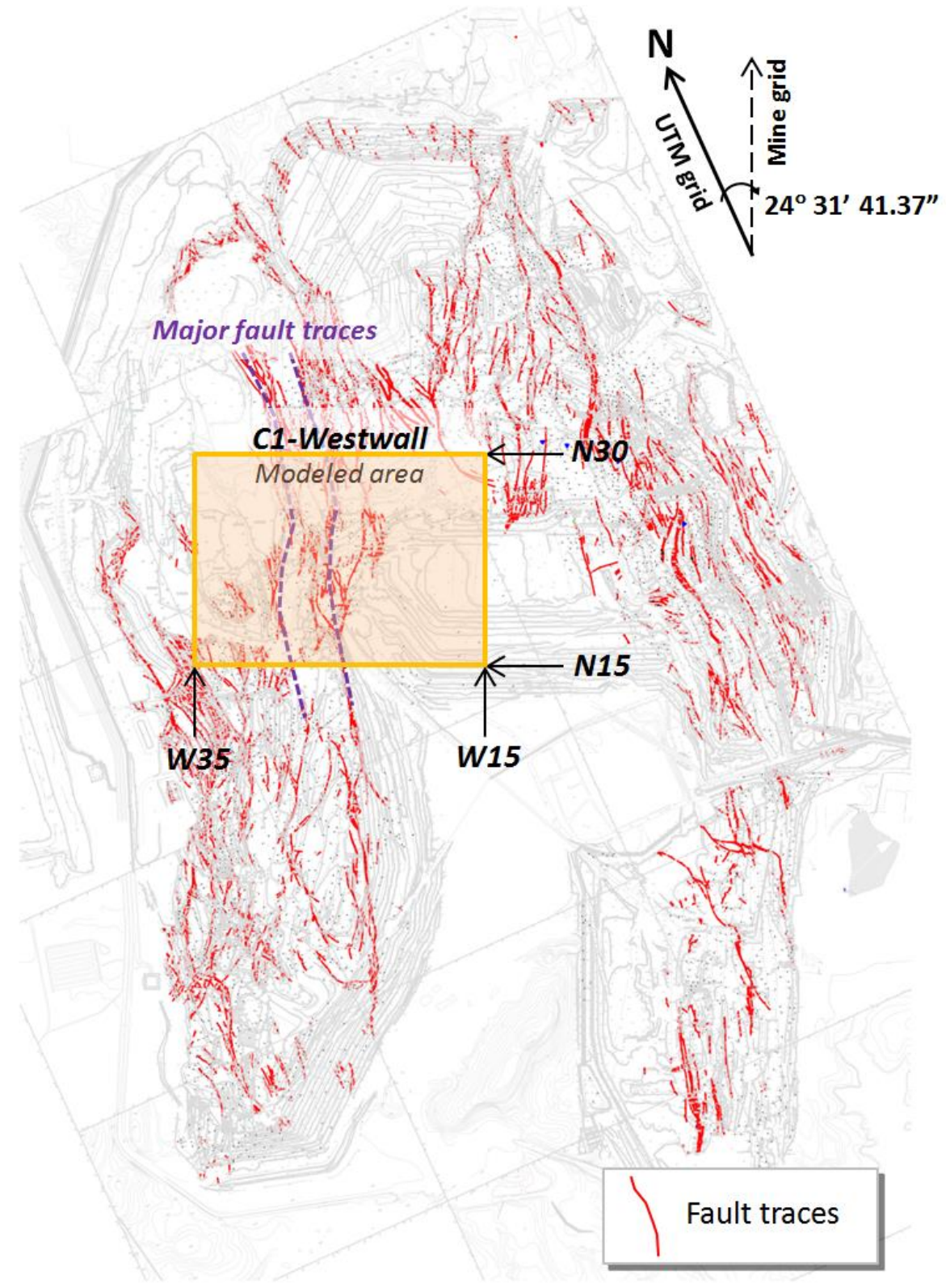

Figure 4 Pit mapping has shown the complex faults system of Mae Moh basin with the modelling boundary of C1-Westwall 


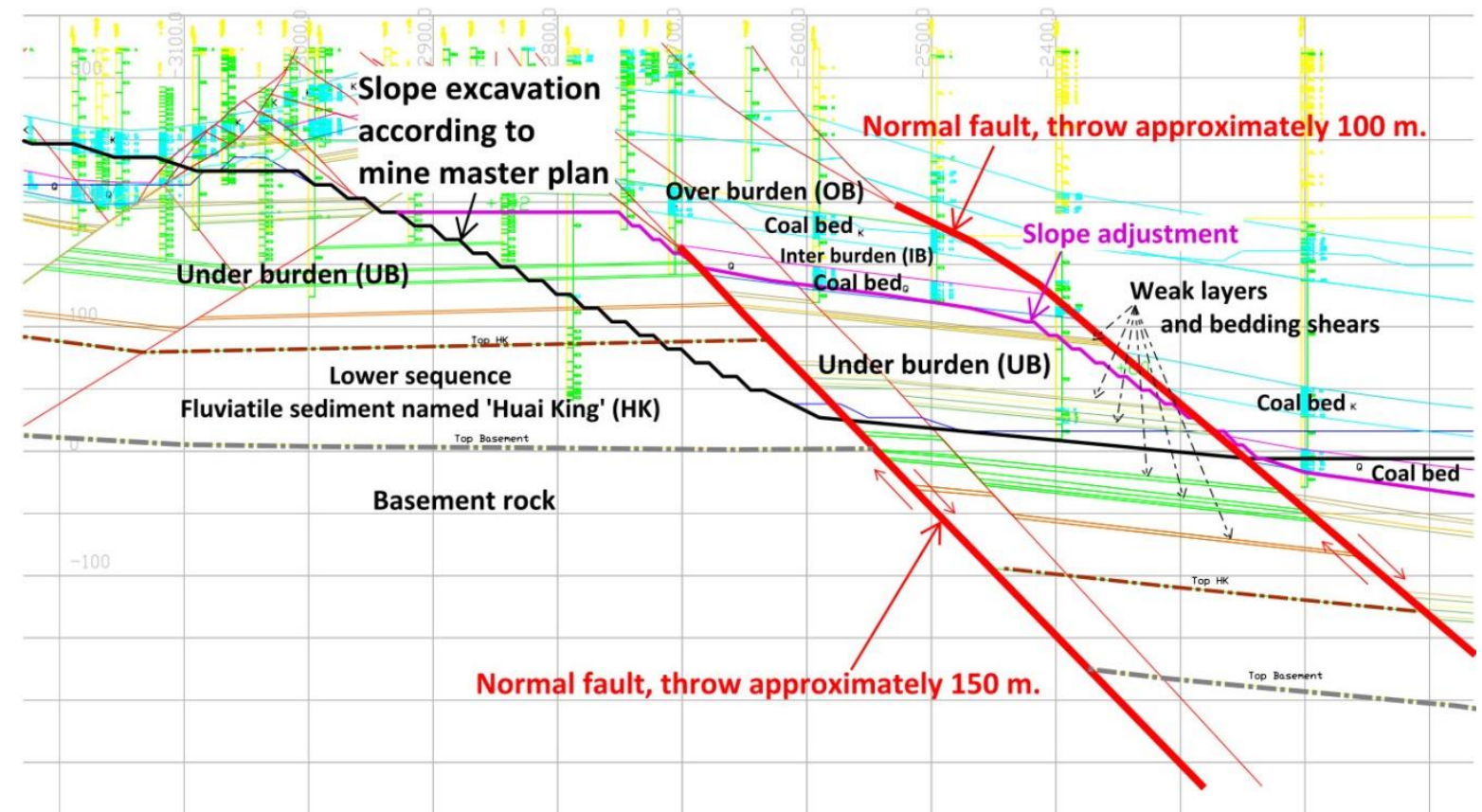

Figure 5 Cross section through N20 represent 'C1-Westwall' geological structure setting. The data has been interpreted and updated from drill hole logging and surface pit mapping

The bedding shears and structures such as normal faults, as shown in Figure 6, are the key features that determine the 'mode of failure'. The potential failure mechanisms of rock slope in Mae Moh Mine are the simple plane sliding or block sliding along the low frictional strength bedding shears (Thailand-Australia Lignite Mines Development Project 1985). Pipatpongsa et al. (2011) had reported the results of shear strength test of clay seam in bedding shears from various testing method are consistently ranged between 15 and $17^{\circ}$, which quite conformed to, but slightly higher than the long-term design parameters that used in effective stress stability analysis of Mae Moh Mine slope, which was reviewed by so many consultants e.g. McMahon (1990), Sullivan (1990), Brawner (1990) and Dight (1994), ranged between 12 and $17^{\circ}$.

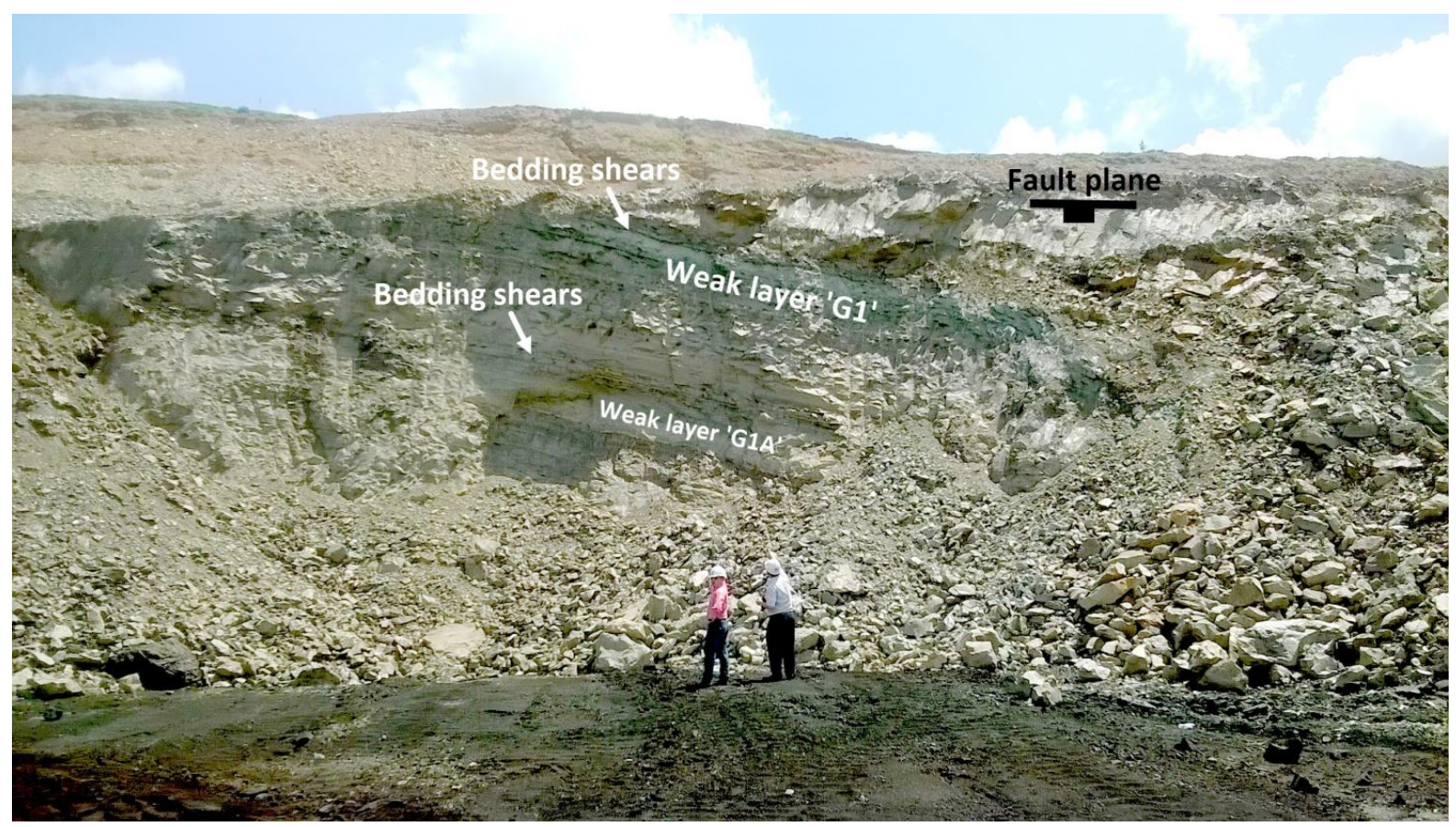

Figure 6 Major weak layers, bedding shears and fault that typically dictate the failure mode in Mae Moh Mine rock slope 
The rock mass, grey claystone is the predominant materials in Mae Moh basin as reported by Thailand-Australia Lignite Mines Development Project (1985), composes the most of final slope that should be maintained the stability through the life of mine. The geotechnical properties of the grey claystone is summarised in Table 1. This can be implied that it is generally one class of the weak mudrocks or clay shales which physical characteristics and behaviour are as summarised by Martin and Stacey (2013).

Table 1 Mae Moh basin grey claystone geotechnical properties (modified from Thailand-Australia Lignite Mines Development Project 1985)

\begin{tabular}{lccccc}
\hline \multicolumn{1}{|c}{ Property } & Mean & $\begin{array}{c}\text { Standard } \\
\text { deviation }\end{array}$ & $\begin{array}{c}\text { Minimum } \\
\text { test value }\end{array}$ & $\begin{array}{c}\text { Maximum } \\
\text { test value }\end{array}$ & $\begin{array}{c}\text { Number } \\
\text { of tests }\end{array}$ \\
\hline Total density $\left(\mathrm{t} / \mathrm{m}^{3}\right)$ & 1.95 & 0.15 & 1.07 & 2.54 & 324 \\
\hline Unconfined compressive strength $(\mathrm{MPa})$ & 4 & 2 & 0 & 14 & 206 \\
\hline Strain at failure $(\%)$ & 2.20 & 0.84 & 0.30 & 6.70 & 205 \\
\hline Effective cohesion $(\mathrm{kPa})$ & 500 & - & - & - & - \\
\hline Effective friction angle $\left({ }^{\circ}\right)$ & 33 & - & - & - & - \\
\hline
\end{tabular}

\section{Pit wall stability concerns}

According to the conceptual adjustment plan, the C1-Westwall stability is concerned with the massive block sliding controlled by multiple bedding shears. If the problem was considered in typical 2D plane strain analysis, the slope is obviously unstable. The problem of this massive block stability has been brought into $3 \mathrm{D}$ analysis as a result of the structural trends i.e. bedding dip directions, are oblique toward the south-east direction, ranged between 102 and $214^{\circ}$, instead of simple plunge direct toward the slope opening, as shown in Figure 7.

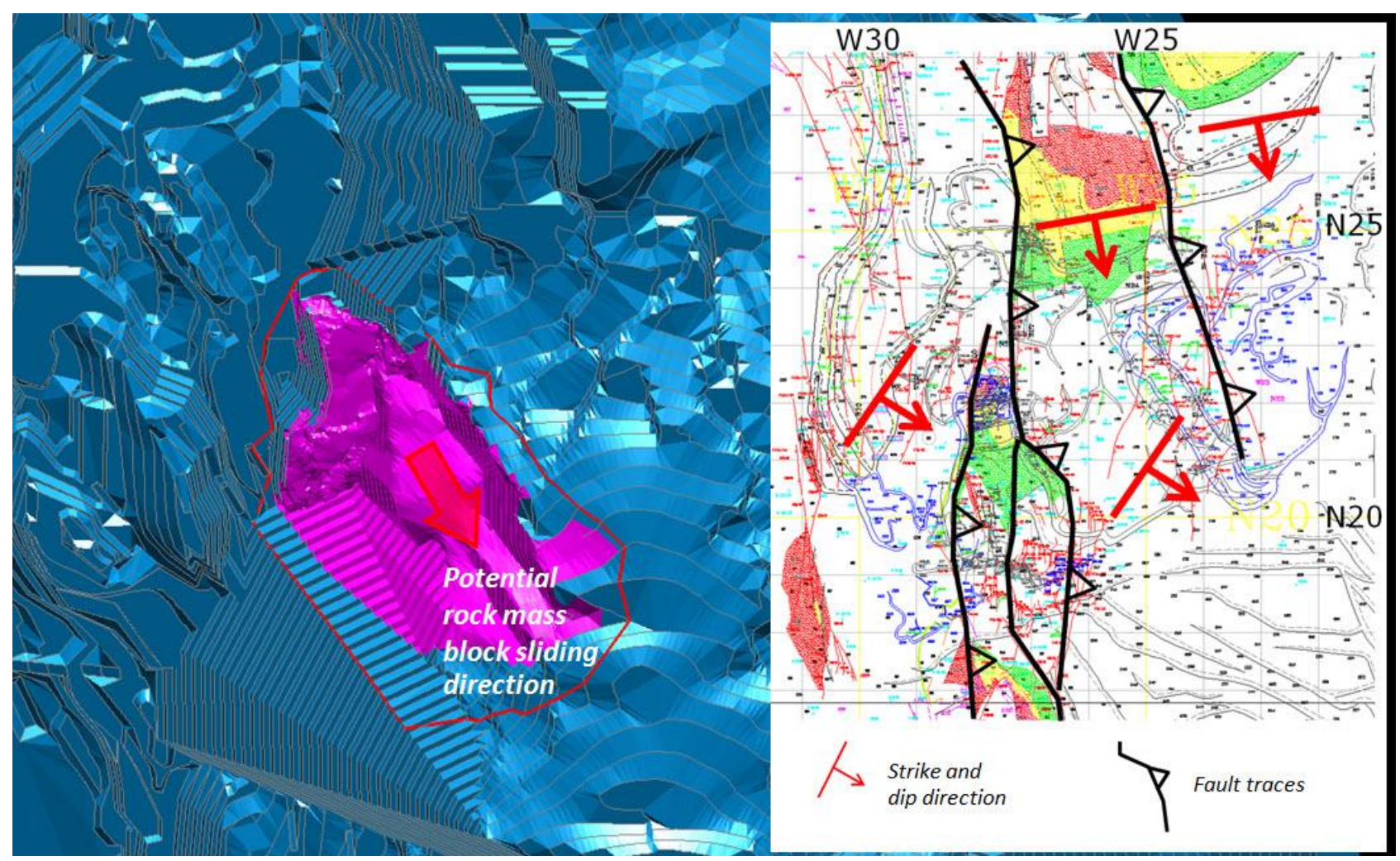

Figure 7 The orientations of bedding dip and dip direction with fault strike of C1-Westwall area 


\section{$4 \quad$ Three-dimensional discrete blocks numerical modelling}

The first full-scale 3D of Mae Moh Mine pit slope, called 'Area 4.1', was performed by Leelasukseree and Mavong (2012). The model comprises 1,014,580 tetrahedral meshes with average edge length $10 \mathrm{~m}$ of deformable blocks, with the model box size $700 \mathrm{~m}$ wide, $600 \mathrm{~m}$ long and $320 \mathrm{~m}$, which is merely five times smaller than C1-Westwall.

The 3D blocks model in the C1-Westwall case, with problem domain of 1,500 $\mathrm{m}$ wide, $2,000 \mathrm{~m}$ long and $800 \mathrm{~m}$ high box size, has been tried to create in many different ways. As a purpose on preliminary study, the most reasonable and practical way is the rigid discrete blocks cutting model to examine the model response to the changes in structural orientations. Consequently, the first series of blocks model configurations in nine different scenarios of the structural orientations as represented in Table 2 were ready to run in $3 D E C^{\circledR}$.

Table 2 Model setup and running scenarios

\begin{tabular}{ccccccccc}
\hline Scenarios & $\begin{array}{c}\text { Dip } \\
\text { direction }\end{array}$ & $\begin{array}{c}\text { Dip } \\
\text { angle }\end{array}$ & Blocks & Regions & $\begin{array}{c}\text { Joints normal } \\
\text { stiffness }\end{array}$ & $\begin{array}{c}\text { Joints } \\
\text { shear } \\
\text { stiffness }\end{array}$ & $\begin{array}{c}\text { Joints } \\
\text { friction } \\
\text { angle }\end{array}$ & $\begin{array}{c}\text { Model } \\
\text { running } \\
\text { steps }\end{array}$ \\
\hline 1 & $158^{\circ}$ & $14^{\circ}$ & 175,553 & 8,940 & 10 e9 & 5 e9 & 12 & 10,000 \\
\hline 2 & $158^{\circ}$ & $4^{\circ}$ & 195,385 & 8,417 & 10 e9 & 5 e9 & 12 & 10,000 \\
\hline 3 & $158^{\circ}$ & $23^{\circ}$ & 195,963 & 9,825 & 10 e9 & 5 e9 & 12 & 10,000 \\
\hline 4 & $102^{\circ}$ & $14^{\circ}$ & 216,639 & 10,043 & 10 e9 & 5 e9 & 12 & 10,000 \\
\hline 5 & $102^{\circ}$ & $4^{\circ}$ & 179,053 & 8,767 & 10 e9 & 5 e9 & 12 & 10,000 \\
\hline 6 & $102^{\circ}$ & $23^{\circ}$ & 270,677 & 12,237 & 10 e9 & 5 e9 & 12 & 10,000 \\
\hline 7 & $214^{\circ}$ & $14^{\circ}$ & 179,525 & 7,328 & 10 e9 & 5 e9 & 12 & 10,000 \\
\hline 9 & $214^{\circ}$ & $4^{\circ}$ & 190,632 & 7,908 & 10 e9 & 5 e9 & 12 & 10,000 \\
\hline 9 & $214^{\circ}$ & $23^{\circ}$ & 169,092 & 7,331 & 10 e9 & 5 e9 & 12 & 10,000 \\
\hline
\end{tabular}

Each scenario is the case of the variation of bedding plane orientations which are dip directions and dip angles combined, from the minimum, average and the maximum value. For the dip direction, these are 102,158 and $214^{\circ}$ respectively. And for dip angles are 4,14 and $23^{\circ}$ respectively. Based on the slope face orientation of C1-Westwall, which is approximately $114^{\circ}$, these could be implied that the most adverse scenario for blocks sliding is scenario 6 , the combination of $23^{\circ}$ dip angle with dip direction $102^{\circ}$, within the approximately $\pm 20^{\circ}$ range relative to slope face orientation stated by Hoek and Bray (1981).

The blocks model comprises four rigid blocks, which three of them were fixed except the centre. The centre region was completely cut through by two cross bedding joint sets, perpendicular to bedding dip for each scenario with the block size of $20 \times 20 \times 20 \mathrm{~m}^{3}$, as shown in Figure 8 . The shear strength of rock joints was assigned as the minimum value of bedding shears, for the long-term parameters, which are $12^{\circ}$. The existing of water pressure in joints and bedding shears is precluded. 


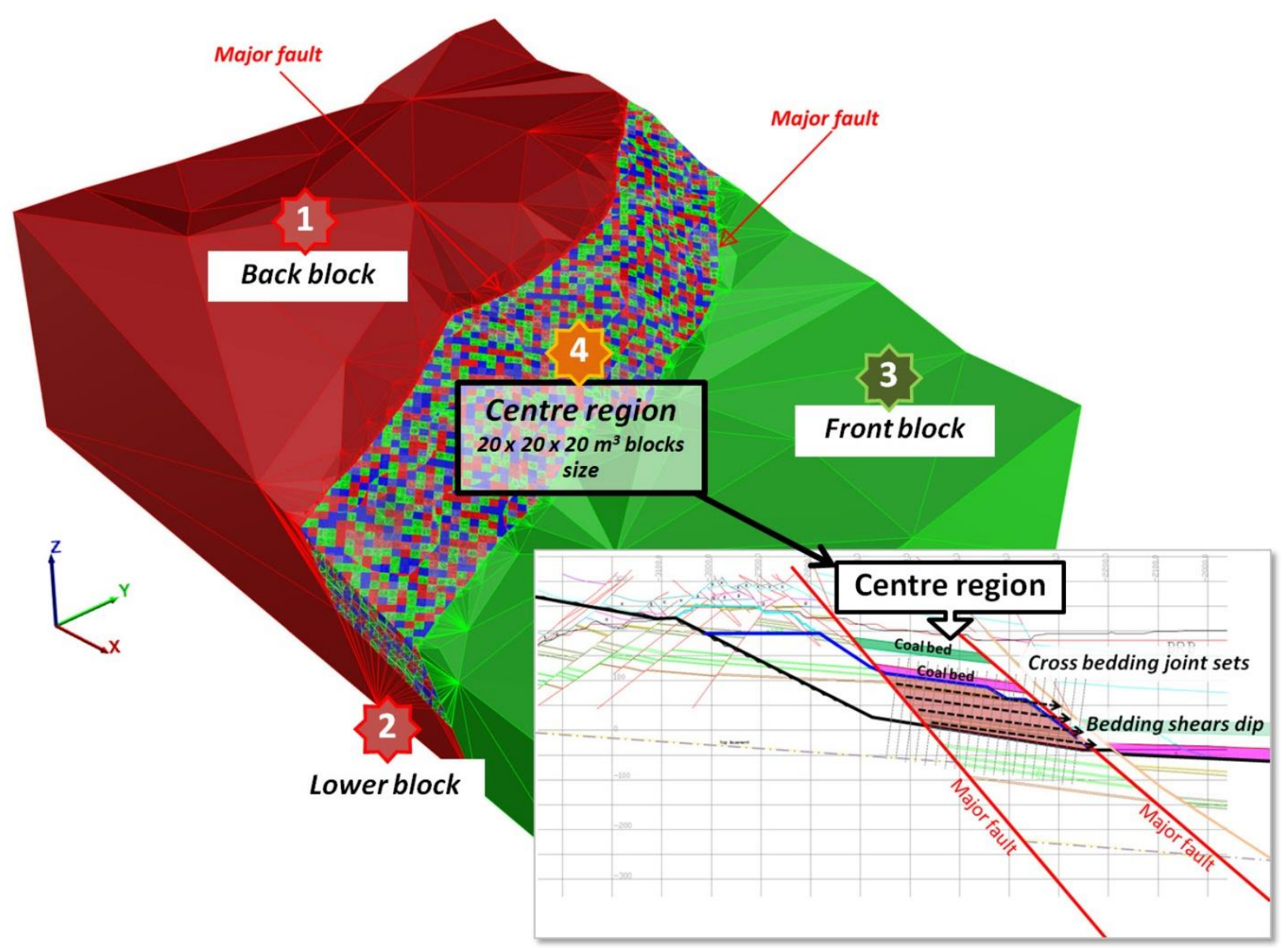

Figure 8 3D discrete blocks cutting model of C1-Westwall

\section{Deformation patterns}

The modelling results are represented by displacement patterns of the discrete blocks, as shown in Figure 9. The expected result is the deformation patterns of the optimistic scenarios, i.e. scenario 2,5 and 8 with varied dip direction combined with gentle dipping plane $4^{\circ}$, shown the small movement regions limited on the upper blocks with displacement approximately $0.11 \mathrm{~m}$ after 10,000 steps calculation. The pessimistic scenarios, blocks with dip angle 14 and $23^{\circ}$ with the most adverse bedding shears plane dip direction $102^{\circ}$, i.e. scenario 4 and 6 respectively, has high magnitude of displacement, approximately 0.24 to $0.39 \mathrm{~m}$, but surprisingly quite lower than expected. One assumption is the effect of 'block-size' and confining interaction between blocks that would not be experienced in $2 \mathrm{D}$ analysis. The lowest movement magnitude is approximately $0.04 \mathrm{~m}$ in scenario 7 and 9 . 


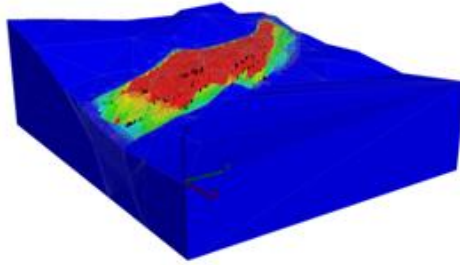

Scenario 1

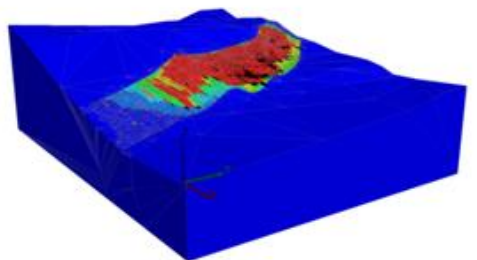

Scenario 4

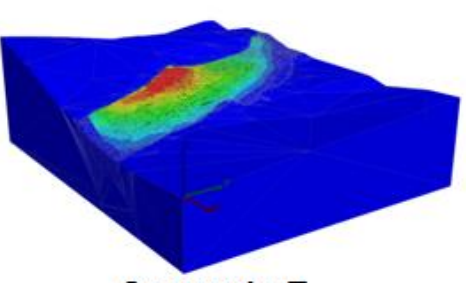

Scenario 7

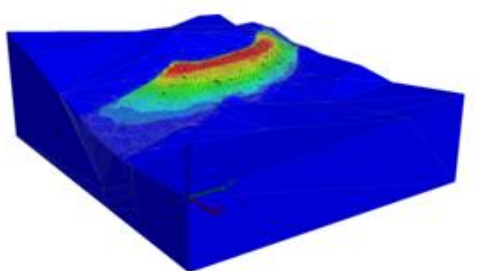

Scenario 2

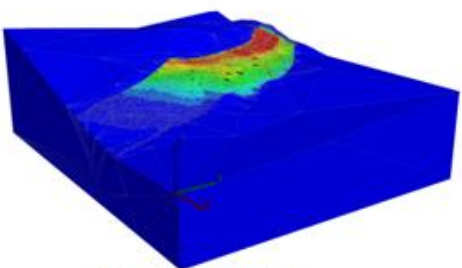

Scenario 5

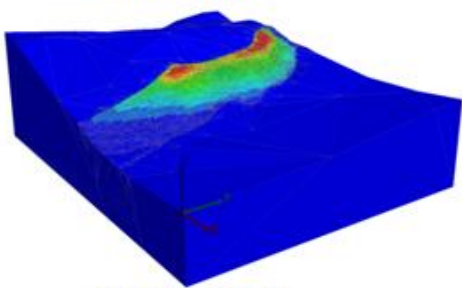

Scenario 8

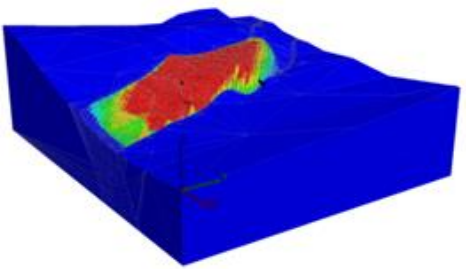

Scenario 3

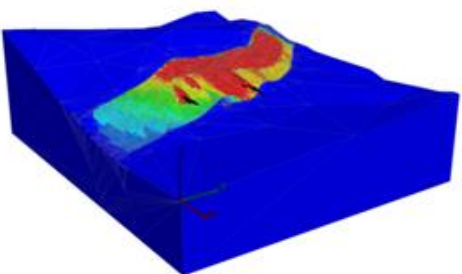

Scenario 6

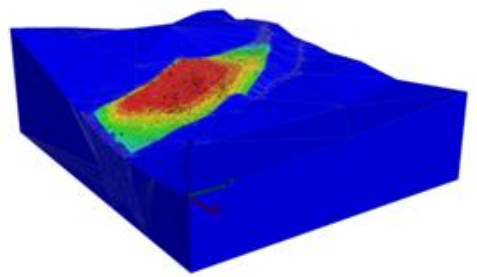

Scenario 9

Figure 9 Displacement contours of discrete blocks model scenarios

The result has also shown that the movement regions are mainly occupied most of upper range of the rock mass which referred to the block overlying on the shallow bedding shears layers, 20-40 m below ground surface, and has the tendency of sliding directly to the slope opening. This will be implied that, the reinforcement, or other mitigation methods are still be needed to prevent the movement during the operation for the large area of this under burden rock slab.

Additionally, in the oblique scenario 1 and 3, which bedding oriented toward the south-east direction, $158^{\circ}$ dip direction, with dipping ranged between 14 and $23^{\circ}$, the movement regions extended to the toe region of batter, the buttress of in situ material will be needed to lower the risk of overall instability of under burden rock blocks which can be affects to the continuity of the project that will be progressed deep down to the south-eastern or the middle of the pit.

Finally, the adjustment plan is primarily evaluated from this little numerical 'experiment', the more details must will be work furthermore for the effect of blocks size with the more 'realistic' variation of the structural orientations, which affect the results significantly.

\section{Conclusion remarks}

The C1-Westwall slope re-design concept was primarily assessed by 3D discrete numerical modelling, due to the nature of geological setting and potential failure mode, blocks sliding. The 3DEC ${ }^{\circledR}$, which has the capability in explicit joints modelling, which suitable for the case of Mae Moh Mine rock slope, was selected as the tool of the trade. The nine scenarios of block joints cutting and bedding structure orientations were analysed to get the results and better understanding of the rock blocks failure tendency in relation to the orientations of controlling structures.

The result shown that rock blocks movement are dominated mostly in the shallow upper regions, overlying on the bedding shears layers, $20-40 \mathrm{~m}$ below ground surface. There still be needs for some sorts of reinforcement and buttress to prevent and minimise the risk of rock slope movement, when the operation will be progressed deep down to the south-eastern or the middle of the pit. 
The great indirect benefit which is gained from this 'experiment' is the awareness to the potential hazard that proved to be existed in this batter adjustment which cannot be ignored and needed to rethink and thoroughly examine furthermore. Hopefully this is the first step to the effective slope design concept of the Mae Moh Mine pit wall for the long-term mine operation and optimise the utilisation of resource for national power security.

\section{Acknowledgement}

The authors would like to express the most gratitude to the Mae Moh Mine Engineering Department, Geotechnical Engineering Department for granting and providing the supportive data and the opportunity to sharpen the 3D modelling skill, and the department of mining and petroleum engineering, Chiang Mai University, for the encouragement, knowledge and motivation to the creation on this work.

\section{References}

Brawner, CO 1990, Geotechnical Review - Mae Moh Mine, Thailand.

Dight, PM 1994, Report on Geotechnical Site Visit Mae Moh Mine, Thailand.

Hoek, E \& Bray, J 1981, Rock Slope Engineering, 3rd edition, The Institution of Mining and Metallurgy, London.

Itasca Consulting 2007, 3DEC 3 Dimensional Distinct Element Code, Itasca Consulting Group, Inc., www.itascacg.com

Leelasukseree, C \& Mavong, N 2012, 'Initial slope stability study of undercut slope at Area 4.1 Mae Moh Mine, Lampang, Thailand', in C Hawkes (ed.), Proceedings of the 21st Canadian Rock Mechanics Symposium, Canadian Rock Mechanics Association and Canadian Institute of Mining, Metallurgy and Petroleum, Edmonton, pp. 209-217.

Martin, CD \& Stacey, PF 2013, 'Pit slopes in weathered and weak rocks', in PM Dight (ed.), Proceedings of the International Symposium on Slope Stability in Open Pit Mining and Civil Engineering, Australian Centre for Geomechanics, Perth, pp. 3-28. McMahon, B 1990, Report on Geotechnical Site Visit Mae Moh Mine, Thailand.

Mine Engineering Department 2015, Mae Moh Mine Stage Plan, Electricity Generating Authority of Thailand, Thailand.

Pipatpongsa, T, Heng, S, Likitlersuang, S, Mungpayabal, N \& Ohta, H 2011, 'Investigation of mechanical properties of clay seam in bedding shears of the Mae Moh open-pit mine of Thailand', in MA Shahin \& HR Nikraz (eds), Proceeding of the International Conference on Advances in Geotechnical Engineering, Department of Civil Engineering, Curtin University, Perth, pp. 209-220.

Sullivan, TD 1990, Report on Geotechnical Review, Mae Moh, Thailand.

Thailand-Australia Lignite Mines Development Project 1985, Mae Moh Geotechnical Report Volume 1 to 5, Electricity Generating Authority of Thailand, Thailand. 